\title{
PROFESE VĚDKYNĚ OPTIKOU PRVNÍCH PŘíRUČEK PRO VOLBU ŽENSKÝCH POVOLÁNÍ
}

\author{
DANA MUSILOVÁ
}

\section{PROFESSION OF A SCIENTIST THROUGH THE PRISM OF THE FIRST CAREER GUIDANCE BOOKS FOR WOMEN}

This contribution traces whether and in what way career guidance books for women published in the first third of the $20^{\text {th }}$ century presented information about scientific work, necessary qualification, and subsequent job opportunities. Information gained from the guidebooks is then compared with respect to its content, extent, and validity.

Keywords: female scientists - advice on career choice - guidance books

DOI: $10.14712 / 23365730.2018 .27$

Vědkyně se staly předmětem zájmu badatelů a zejména badatelek v době, kdy se v české (historické) vědě začaly etablovat nové výzkumné metody. ${ }^{1}$ Jedním z prvních příspěvků k odborné diskusi o působení žen ve vědě byl seminář „Bádají ženy jinak?“, na základě jehož diskuse vznikl sborník s texty nastiňujícími jednak tehdejší stav bádání, jednak možná metodologická východiska dalšího výzkumu. ${ }^{2}$ Od té doby uplynulo více než dvacet let, během nichž vznikla řada textů o postavení žen v české, respektive československé vědě. ${ }^{3}$ Tyto práce se soustřed'ují prioritně na vstup prvních žen do vědy, zejména v institucionální rovině. Stranou zájmu zůstává výzkum identity, motivace a každodennosti samotných věd-

1 Daniela TinkovÁ, ,Žena“ “jako prázdná kategorie? Od (wo)men’s history ke gender history vápadoevropské historiografii posledních desetiletí 20. století, in: Milena Lenderová (ed.), Dějiny žen aneb evropská žena od středověku do 20. století v zajetí historiografie, Pardubice 2006, s. 19-32.

2 Magdalena Pokorná (ed.), Práce z dějin vědy 3, Praha 2002, s. 141-250.

3 Srovnej např.: Gerhard OBerkofler, Käthe Spiegel. Aus dem Leben der altösterreichischen Historikerin und Frauenrechtlerin, Innsbruck - Wien - Bozen 2005; Soňa ŠTrBáŇovÁ, Ženy ve védě v letech 1840-1989, in: Marcela Linková (ed.), Trans/formace: gender, věda a společnost, Praha 2007; Milena LenderovÁ a kol., Žena $v$ českých zemích od středověku do 20. století, Praha 2009, s. 443-449; Bohumil Neumann, Milada Paulová (1891-1970). Přiběh cesty $k$ dosaženi prvni ženské docentury v Československu v roce 1921, rigorózní práce PedF UK, Praha 2009; Pavel ČECH, Nebýt doma prorokem. Gerty Coriová na cestě za Nobelovou cenou, in: Pavla Vošahlíková - Jiří Martínek a kol., Cesty k samostatnosti. Portréty žen v éře modernizace, Praha 2010, s. 190-215; Jiří MartíneK, Radost z poznání nemusí vést k uznání. Julie Moschelesová, in: tamtéž, s. 176-189; Anna Falisová, Prvá docentka medicíny Božena Štárová-Kuklová. Žena vo vede a na vedúcom poste, in: Gabriela Dudeková a kol., Na cestě k modernej žene. Kapitoly z dejín rodových vzt’ahov na Slovensku, Bratislava 2011, s. 643- 657; Jana MAlínskÁ, „, My byly jsme a budeme! “, Praha 2013; Dana MusilovÁ, Ženy v intelektuálnich profesich v první polovině 20. století, Studia historica Nitriensia 14/1, 2014, s. 49-61; Ivo KRAUS, Ženy v dějinách matematiky, fyziky a astronomie, Praha 2015; Jaroslava Hoffmannová, Prvenství žen. Ženy iniciativní, vzdělané a tvořivé, Praha 2016. 
kyň. Nabízí se například otázka, kde mohly absolventky vysokých škol uvažující o vědecké kariéře získat potřebné informace a motivaci pro své rozhodování.

Na prvním místě se nabízí (širší) rodina - otcové, bratři a další příbuzní -, na druhém okruh př́tel dané rodiny. $\mathrm{V}$ době, kdy z univerzit odcházela první generace absolventek, se objevil ještě jeden zdroj informací, zcela nezávislý na rodinném zázemí: poradenství pro volbu ženských povolání. ${ }^{4}$ U jeho počátků stáli dva muži: Leopold Weigner (1866-1920) a Josef Kafka (1858-1929). Prvně jmenovaný vydal již v roce 1911 př́ručku zahrnující nabídku ženských profesí v průmyslu, řemesle a obchodě. ${ }^{5}$ Josef Kafka, kustod Národního muzea a redaktor časopisu Št’astný domov, zahrnul do své př́ručky rovněž intelektuální profese. Byl přesvědčeným zastáncem tradičního pojetí ženské role, které usilovně a dlouhodobě propagoval ve svém časopise. Na druhé straně si velmi dobře uvědomoval závažné důsledky modernizačních změn pro ženskou populaci. Z této potřeby vznikla nová příručka pro volbu ženských povolání. ${ }^{6}$ Tato a další příručka, o níž se ještě zmíníme, jsou zajímavým dokladem toho, jaké představy měli jejich autoři o akademických profesích a jakým způsobem je předávali veřejnosti. Můžeme rovněž sledovat posun těchto představ a jejich přenášení v čase.

Josef Kafka projevil ve svých úvahách o budoucnosti ženské (produktivní) práce značnou míru předvídavosti. Předpokládal, že po skončení války bude mnohem více žen než dř́ve hledat pracovní uplatnění, a to ze tří důvodů: ještě více vzroste nepoměr mezi počtem žen a mužů v populaci, zhorší se životní podmínky a současně zvýší nároky na konzum. Předvídal rovněž rozšíŕení pracovních možností pro ženy v oborech vykonávaných do té doby převážně nebo výhradně muži, mezi nimi rovněž v oblasti akademických profesí. ${ }^{7}$ Z uvedených důvodů se rozhodl vytvořit příručku pro volbu ženských povolání, která by svým obsahem předjímala budoucí vývoj.

Čtenáři př́ručky, která vyšla uprostřed první světové války, se jistě nemálo podivili, když mezi výčtem třinácti skupin ženských profesí nalezli rovněž následující ,akademická povolání“: bakteriologická laborantka, docentura a profesura, knihovnictví, lékárnictví, lékařství, muzejní konzervátorka, vyrovnávací správce, učitelka vyšších obchodních škol, učitelka střední školy, vědecká spolupracovnice. ${ }^{8}$ Veřejnost sice již od přelomu 19. a 20. století čítávala oznámení o promocích lékařek, filozofek a farmaceutek, ale o jejich uplatnění věděla ve skutečnosti jen velmi málo. Třeba i proto, že řada absolventek vysokoškolského studia dala přednost sňatku před pracovní kariérou.

Josef Kafka nezpochybňoval ženskou emancipaci a její důsledky, neupíral ženám právo na profesní realizaci, na druhé straně však považoval za hlavní povolání ženy mateřství, manželství a vedení domácnosti; ve své př́ručce jej klade na první místo pomyslné profesní

4 Poradenství pro volbu povolání se v českých zemích rozvíjelo již od počátku 19. století. S rychle rostoucím počtem žen v sekundární a terciární sféře ekonomiky vznikla na přelomu 19. a 20. století potřeba specifického profesního poradenství pro dívky.

5 Leopold WeIGNer, Nové dráhy výdělečné práce ženy. Žena v průmyslu, řemesle a obchodě. Rádce při volbě povolání ženy pro rodiče, poručníky, školy a dorůstajíci mládež, Praha 1911, druhé vydání tamtéž v roce 1914.

6 Josef KAFKA, 350 ženských povoláni: př́ručka nezbytná pro rodiče, jejich zástupce, vychovatele, rádce mládeže divčí, divky $i$ ženy všech tř́d, jež se připravuji k manželství a hledaji povoláni a výdělek, Praha 1916. Autor u každé profese vymezuje kvalifikační předpoklady, pracovní náplň a nastiňuje možnosti uplatnění na trhu práce.

7 Tamtéž, s. 4.

8 Tamtéž, s. 231-238. 
hierarchie. Na druhém pak uvádí profese, které mohla žena vykonávat, aniž by opouštěla domov. Kromě tradičních profesí (šití oděvů a prádla, vyšívání, pletení apod.) zařadil rovněž překladatelství. Tento postoj, filozoficky zdůvodněný, dlouhodobě propagoval nejen v časopise Št’astný domov, ale i v četných pracích věnovaných vedení domácnosti. Hlavní př́nos ženy nespatřoval v pouhé reproduktivní práci, nýbrž v citové výchově rodinných př́islušníků, již považoval za zásadní pro pokrok a záchranu lidstva. Pokud by tedy žena vstoupila „do tvrdého zápasu o bytí a do soutěže talentư", poškodila by tím vlastně budoucnost lidstva. Josef Kafka staví ženu s jejími „vrozenými“ vlastnostmi (vyšší morálka, citovost, empatie, ochota k oběti) do role spasitelky světa. ${ }^{9}$ Jak už bylo výše řečeno, neupírá ženám právo vstupovat ,do soutěže talentư“, nebot' má stejný rozum a schopnosti používat ho jako muž, avšak za „cenu potlačeni jemnějšiho citového bytí a tedy také oběti dobrovolného celibátu“. ${ }^{10}$ Josef Kafka zřejmě ani v nejbujnější fantazii nepředpokládal, že by žena vstupující do „soutěže talentư“ mohla uvažovat o spojení pracovní kariéry s rodinným životem tak, jak to bylo běžné u mužŭ. Kromě filozofických úvah však řešil rovněž praktické otázky spojené s volbou profese, napríklad finanční náklady na profesní průpravu.

Vrat’me se však k ,akademickým povoláním“, zmíněným na počátku textu. Josef Kafka je definuje jako profese, $\mathrm{k}$ jejichž výkonu je třeba akademického vzdělání, bud' vysokoškolského, nebo středoškolského. Vědecká kariéra byla ovšem striktně podmíněna vysokoškolským vzděláním v prríslušném vědním oboru, proto se soustředíme pouze na ,akademická povoláni“" splňující tuto podmínku: „,ocentura a profesura“, farmacie a lékařství. Autor vztahuje „docenturu a profesuru“ k následujícím oborům: filologie, historie, zeměpis, archeologie, př́rodní vědy, fyzika, chemie, matematika a filozofie. Ve zvláštní kapitolce věnované medicíně odkazuje mezi možnými pracovními pozicemi pro lékařky rovněž na možnost působení na univerzitě. $\mathrm{V}$ době, kdy Kafka shromažd'oval podklady pro příručku, působily tři absolventky medicíny na klinikách lékařské fakulty české univerzity jako asistentky. ${ }^{11}$ Mezi obory s vědeckým potenciálem naopak vůbec nezmiňuje farmacii. Pozornost soustř̌ed'uje pouze na stávající praxi, znemožňující absolventkám studia farmacie provozovat lékárnu pod vlastním jménem.

Josef Kafka soudí, že „docentura a profesura poskytuje málo naděje na pramen existen$c e^{\text {“, }}$, př́prava k ní trvá velmi dlouho a žena musí mít dostatečné finanční zázemí. ${ }^{12}$ Své tvrzení dokládá délkou pregraduální a postgraduální př́ípravy a nutností dlouhodobě vědecky pracovat a publikovat.

Na Kafkovu př́ručku navázala v roce 1929 Juliana Lancová (1878-1962), zakladatelka a propagátorka poraden pro volbu povolání v Československu a editorka Praktického rádce při volbě povolání dívek. ${ }^{13}$ Nabízí se srovnání priorit, obsahu a doporučení obsažených

9 Tento způsob uvažování je typický pro české feministické myšlení od jeho počátků až do poloviny 20. století. Srov.: Marie BahenskÁ - Libuše HeczKová - Dana Musilová, Iluze spásy. České feministické myšlení 19. a 20. století, České Budějovice 2011.

10 J. KAFKA, 350 ženských povolání, s. 20.

11 Jaroslava Hoffmannová uvádí, že v roce 1909 se první žena stala asistentkou na české lékařské fakultě, další následovaly v roce 1910, respektive 1914. J. HofFMANNOvá, Prvenství žen, s. 91.

12 J. KAFKA, 350 ženských povolání, s. 231.

13 Juliana Lancová, Kniha ženských zaměstnání. Praktický rádce při volbě povoláni divek, Praha 1929. Autorkami textů o jednotlivých profesích jsou absolventky př́slušného pregraduálního studia, např. MUDr. Anna Lankašová-Burianová. Rovněž tato př́ručka uvádí u každého povolání kvalifikační předpoklady, pracovní náplň a možnost uplatnění na trhu práce; informace jsou však podrobnější a odrážejí profesní zkušenosti jednotlivých autorek. Přríručka o ženských profesích nebyla prvním počinem Juliany Lancové v oboru poradenství pro volbu 
v obou prríručkách, jejichž vydání dělilo nejen třináct let, ale rovněž prohloubení procesu ženské emancipace, odlišný pohled editorky na ženu a její postavení ve společnosti a v rodině, více zkušeností s absolventkami vysokých škol a rozvoj poradenství pro volbu povolání po první světové válce. Juliana Lancová nepokládá, na rozdíl od Josefa Kafky, mateřství a s ním související činnost za povolání; výhradní působení ženy ve vlastní domácnosti však za profesi považuje. ${ }^{14}$ Neuvádí akademická povolání jako samostatnou skupinu, ale zařazuje je do jednotlivých odborných skupin podle jejich charakteru.

Juliana Lancová a její spolupracovnice měly při př́pravě příručky nespornou výhodu $\mathrm{v}$ tom, že mohly zohlednit kariéry první generace vědkyň. V roce 1925 se na Univerzitě Karlově habilitovala historička Milada Paulová, roku 1926 na Německé univerzitě v Praze lékařka Hedwig Langeckerová a roku 1928 na Univerzitě Komenského v Bratislavě lékařka Božena Štúrová-Kuklová, dalši ženy působily na vysokých školách jako asistentky. Příručka nabízí uplatnění ve vědě absolventkám filozofických, př́rodovědeckých a lékařských fakult. Větší pozornost věnuje možnosti působení absolventek přírodovědeckých fakult na vědeckých pracovištích a ve výzkumných ústavech, což lze vysvětlit relativně krátkou dobou jejich samostatné existence v rámci univerzit a s tím související potřebou informovat veřejnost. Najdeme zde rovněž výslovné upozornění, že ženy „,musí být opravdu výborně kvalifikované pro vědeckou práci“, nebot’ jsou v této práci „,méně obvyklým jevem než na středoškolské profesuře a musí překonávat předsudky veřejnost $i^{“} .{ }^{15}$ Odkaz na „předsudky veřejnosti“" není ničím novým; podobně se psalo v prvním desetiletí 20 . století o lékařkách usilujících o místa na klinikách. Působení akademiček ve vědecké sféře jistě mělo své esenciálně zaměřené odpůrce, mnohem více tu však působila obava $\mathrm{z}$ konkurence $\mathrm{v}$ prestižních profesích, do té doby výhradně mužských. Tato obava rostla úměrně počtu oborů, v nichž ženy absolvovaly pregraduální vzdělávání. Významně jich přibylo po první světové válce, kdy se ženám otevřely další vysoké školy nebo fakulty.

Nejpodrobnější informace o pregraduálním studiu a možnostech uplatnění po jeho absolvování najdeme v kapitole o lékařské profesi. Je to celkem logické, vezmeme-li v úvahu, že od prvních promocí lékařek uplynulo takřka třicet let a o jejich úspěšném uplatnění v oboru nebylo pochyb. Autorka kapitoly, doktorka Anna Lankašová-Burianová, neopomenula ani možnost lékařek věnovat se vědecké práci „v ústavech a na klinikách, jež umožňuje zvláště schopným získat misto asistenta a pokračovati na dráze vědecké, jejímž vyvrcholením je habilitace “. ${ }^{16} \mathrm{~V}$ době, kdy psala svůj text, byla habilitace skutečně vyvrcholením dvou ženských vědeckých kariér v oboru lékařství $(1926,1928)$. V dané chvíli si nejspíš neuměla představit jejich další kariérní postup v podobě jmenování profesorkou, proto uvedla jako vyvrcholení vědecké kariéry lékařky habilitaci, mající již zcela reálné obrysy.

povolání. Již v roce 1925 vydala publikaci s názvem Správná volba povolání. Praktická príručka pro rodiče, vychovatele, učitele, lékaře, poradce, zaměstnavatele, zaměstnance atd., v níž se však nevěnovala výhradně dívkám.

14 Důvodem, proč Juliana Lancová považuje působení ženy ve vlastní domácnosti za povolání, je nutnost důkladné přípravy a odborného vzdělávání. Výslovně však uvádí, že toto povolání není vhodné pro každou ženu, „nýbrž jen pro tu, která se k němu cítí být povolána“. Odborně vzdělaná neprovdaná žena může najít uplatnění v domácnosti profesně aktivních žen, zejména provdaných, které neopustí svou profesi ani po sňatku. Konstatuje, že takových př́padů přibývá a je třeba se s tím smírit. J. Lancová, Kniha ženských zaměstnání, s. 15.

15 Tamtéž, s. 24.

16 Tamtéž, s. 236. 
Za zmínku rovněž stojí podrobné vyčíslení nákladů na pregraduální studium, které můžeme porovnat s platy vysokoškolských asistentů, což byl první profesní stupeň na cestě $\mathrm{k}$ budoucí vědecké kariéře. Doktorka Lankašová-Burianová zahrnula do celkových nákla-

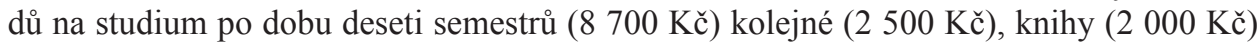
a rigorózní a promoční taxy (1 $200 \mathrm{Kč})$. Vysvědčení o nemajetnosti a výborný prospěch u maturity umožňovaly požádat o osvobození od kolejného a o stipendium. ${ }^{17}$

Platy vyučujících na vysokých školách včetně asistentů ${ }^{18}$ se skládaly ze služného (u asistentů nazývaného remunerací), činovného a výchovného a byly stanoveny státem. Výše činovného se řídila sídlem vysoké školy a souvisela se životními náklady v daném místě. Výchovné náleželo pouze rodičům nezaopatřených dětí a bylo stejné pro všechny veřejné zaměstnance, tedy i vyučující na vysokých školách (1 800 Kč ročně pro jedno dítě, respektive 3000 Kč pro více dětí). Asistenti se dělili podle výše dosaženého vzdělání do dvou kategorií a na této pozici setrvali zpravidla dva roky s možností prodloužení o další dva roky na základě rozhodnutí vysoké školy. Asistent mohl působit na svém místě maximálně osm let, od čtvrtého dokončeného roku ovšem za předpokladu schválení ministerstvem školství a národní osvěty a většinou jen v př́padě, že požádal o habilitaci. ${ }^{19}$

Plat asistentů se odvíjel od zařazení do jedné ze dvou kategorií a délky služebního poměru. V prvním roce a v první kategorii činil 15600 Kč, ve druhém 17400 Kč ročně. Ve druhé kategorii 12600 , respektive 13800 Kč. Poté se platy snižovaly v závislosti na délce služebního poměru. Čím delší byl služební poměr, tím nižší plat asistentovi náležel. Totéž pravidlo sloužilo pro výpočet činovného. ${ }^{20}$ Pravidla pro zaměstnávání asistentů dovolovala na jedné straně rychlou obměnu asistentů, kteří nedokázali splnit nároky kladené na odbornou práci, na talentované působila motivačně a umožňovala jim nastartovat vědeckou kariéru. V zásadě však stále platilo to, co napsal v roce 1916 ve své př́ručce pro volbu ženských povolání Josef Kafka: žena musí mít pro vědeckou kariéru dobré finanční zázemí.

Př́ijem mimořádného či řádného univerzitního profesora mohl vědkyni zajistit život bez existenčních starostí. Plat mimořádného profesora činil na nejnižším služebním stupni 30600 Kč, rádného na téže pozici 39000 Kč ročně. K tomu náleželo činovné stanovené v odlišné výši pro mimořádné a pro řádné profesory, respektive jednotné výchovné, pokud měl profesor v rodině nezaopatřené děti. ${ }^{21}$ Dosáhnout této kvalifikace se do druhé světové války v Československu podařilo pouze třem ženám: lékařkám Boženě Štúrové-Kuklové a Hedwig Langeckerové a historičce Miladě Paulové. Božena Štárová-Kuklová byla jmenována mimořádnou profesorkou v roce 1934 na Univerzitě Komenského v Bratislavě,

17 Tamtéž, s. 237.

$18 \mathrm{Na}$ vysoké škole mohli působit za určitých podmínek asistenti bez nároku na plat. K ustanovení takových asistentů byl nutný souhlas ministerstva školství a národní osvěty.

19 František Morkes, Postavení učitelů v předmnichovském Československu, Praha 1994, s. 19-20.

20 Tamtéž, s. 20-21.

21 Spojení ženské profesní kariéry ve vědě s rodinnými závazky bylo v první polovině 20. století velmi výjimečné. Profesorka Božena Štúrová-Kuklová měla tři děti. Vedení domácnosti a výchovu dětí obstarávala její neprovdaná sestra, což jí bezesporu umožňovalo věnovat se profesní kariéře na univerzitě. Všechny vědkyně bez rozdílu rodinného stavu však musely mít dobře fungující zázemí, at' už ve své rodině, nebo v hospodyni. Ve druhém př́padě se stávaly zaměstnavatelkami a poskytovaly obživu jiné ženě, což Juliána Lancová považovala za ideální spojení a doplňování dvou profesí. A nejen Juliána Lancová: stav, kdy profesně aktivní žena zaměstnávala jinou ženu jako hospodyni či pomocnici v domácnosti, propagovaly liberální feministické aktivistky, typicky Františka Plamínková. 
Hedwig Langeckerová v témže roce, ale o několik měsíců později na Německé univerzitě v Praze, Milada Paulová v roce 1935 na Univerzitě Karlově v Praze. ${ }^{22}$

Juliana Lancová vůbec nezmiňuje ve své prííručce možnost vědecké kariéry absolventek právnického studia a technických oborů. Tuto skutečnost lze vysvětlit tím, že ženy mohly začít studovat tyto obory až v roce 1918 a v době sestavování prŕručky jejich absolventky teprve hledaly (a obtížně nacházely) uplatnění na trhu práce. ${ }^{23}$

Obě příručky pro volbu ženských povolání poskytovaly veřejnosti základní informace o uplatnění žen ve vědě v závislosti na zkušenostech absolventek vysokých škol. Josef Kafka reflektuje zkušenosti první generace, Juliana Lancová má po více než desetiletí od vydání první příručky k dispozici mnohem více informací, zejména k oborům, které mohly ženy studovat už od přelomu 19. a 20. století na lékařských a filozofických fakultách. Její informace obsahují hlubší osobní reflexi možností uplatnění po pregraduálním studiu. Právě tato reflexe mohla být pro ženy směřující k vědecké kariéře zajímavá.

DANA MUSILOVÁ

\title{
Der Beruf der Wissenschaftlerin aus der Sicht der ersten Handbücher für Frauenberufe
}

\section{ZUSAMMENFASSUNG}

Im ersten Jahrzehnt des 20. Jahrhunderts kommen im Anschluss an die wachsende Zahl von berufstätigen Frauen die ersten Handbücher für die Wahl von Frauenberufen auf. Obwohl der Beruf der Wissenschaftlerin für eine Frau jener Zeit fast einem unerreichbaren Traum glich, akzeptiert schon das von Josef Kafka 1916 herausgegebene Handbuch die Existenz der Hochschulbildung für Frauen und bietet für Absolventinnen Möglichkeiten der Betätigung in Wissenschaft und Forschung. Das Handbuch von Juliana Lancová aus dem Jahre 1929 enthält fundiertere und detailliertere Informationen über die Betätigung von Frauen in der Wissenschaft, was auf eine wesentlich größere Menge an praktischen Erfahrungen mit der Berufstätigkeit von Hochschulabsolventinnen zurückzuführen ist. Beide Handbücher stützten sich übrigens auf ihre Erfahrungen, einschließlich der, dass eine Frau für ihre wissenschaftliche Karriere eine gute finanzielle Absicherung benötigt.

Deutsche Übersetzung Wolf B. Oerter

\author{
Dana Musilová \\ Historický ústav Filozofické fakulty \\ Univerzita Hradec Králové \\ Dana.Musilova@uhk.cz
}

22 Petr Svobodný, Tři poznámky k otázce, zda bádaji ženy jinak: případ lékařek, in: Magdalena Pokorná (ed.), Práce z dějin vědy, Praha 2002, s. 223.

23 K uplatnění právniček srov.: Dana Musılová, Z ženského pohledu. Poslankyně a senátorky Národního shromážděni Československé republiky 1918-1939, České Budějovice 2007, s. 67. 